This item was submitted to Loughborough's Institutional Repository (https://dspace.lboro.ac.uk/) by the author and is made available under the following Creative Commons Licence conditions.

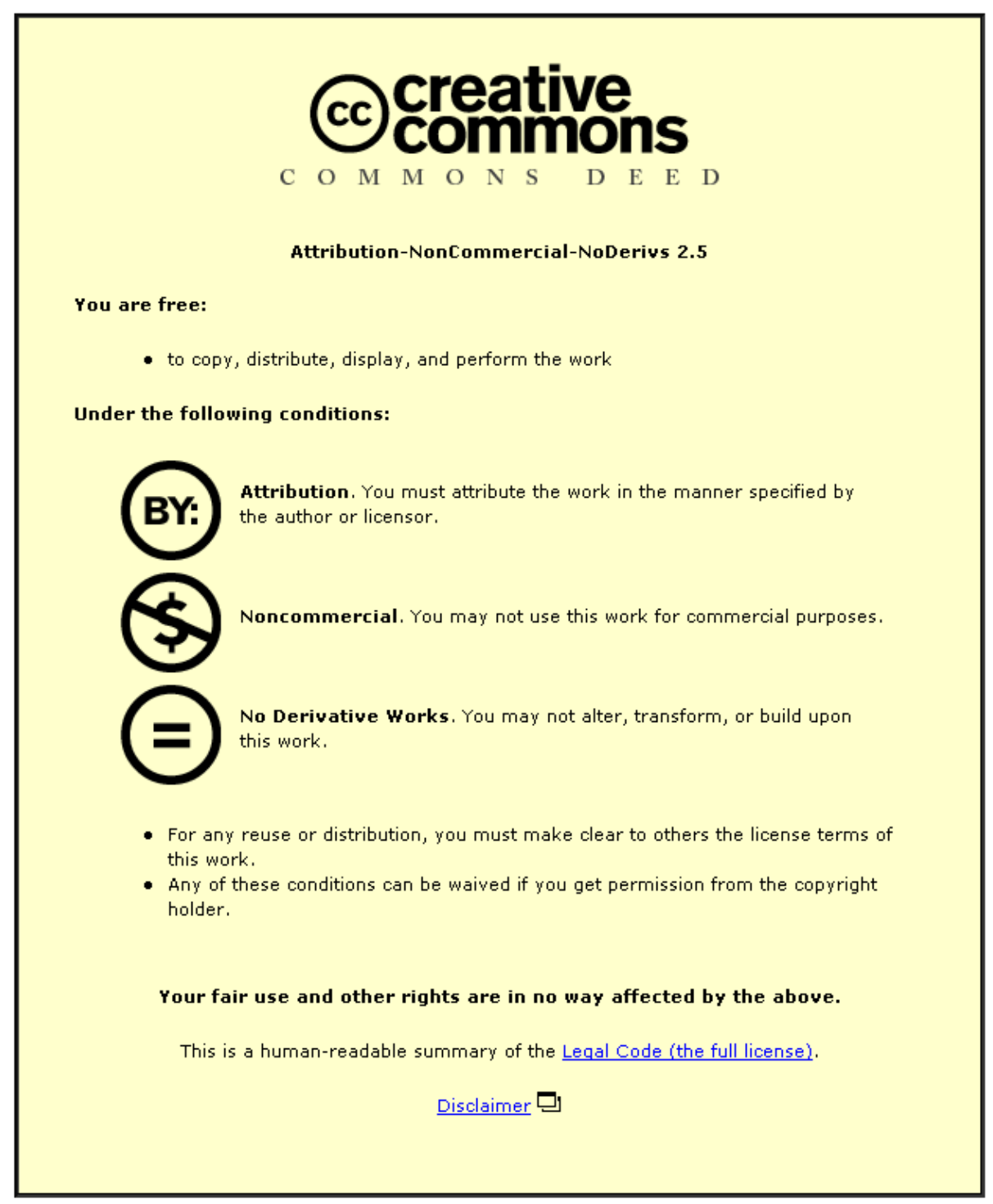

For the full text of this licence, please go to: http://creativecommons.org/licenses/by-nc-nd/2.5/ 


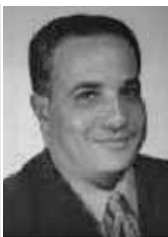

Mohamed Osmani Lecturer, Department Lecturer, Department of Loughborough University, UK
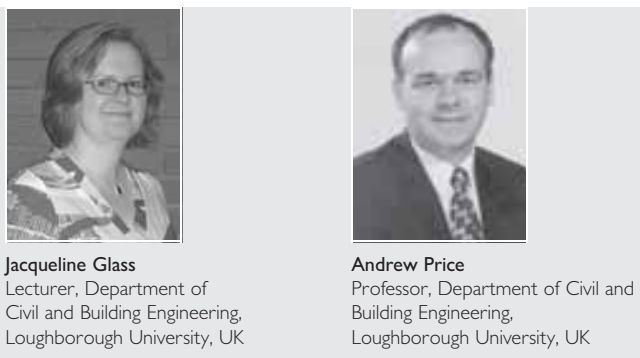

\section{Architect and contractor attitudes to waste minimisation}

M. Osmani Dip Arch, MPhil, CertTHE, J. Glass Dip Arch, Dip BRS, PhD, CertTHE, ILTM and A. Price PhD, MICE, FCIOB

Around $\mathbf{4 2 0}$ million $\mathrm{t}$ of materials are used each year in the construction industry in the UK; however, only $\mathbf{3 6 0}$ million $t$ are incorporated into products. Additionally, construction and demolition activities in the UK generated more than 150 million $t$ of waste in 1998 comprising $40 \%$ from the manufacture of products and $60 \%$ from site-based activities, including an estimated 13 million $t$ of unused materials. Research has been undertaken to assess UK architects' and contractors' attitudes towards waste minimisation, by investigating the integration of waste minimisation strategies into current design processes, examining contractors' existing waste management practices and establishing responsibilities for, and barriers to, managing waste minimisation. A questionnaire survey based on specific and interrelated organisational waste minimisation issues was conducted with architects and contractors and revealed that very few attempts are made to reduce waste during the design process. On the other hand, the results show that contractors are pursuing a more proactive approach to manage on-site waste production through the development of environmental and waste management policies. The results reveal that poorly defined responsibilities are leading to confusion regarding who should control and monitor waste management. Both architects and contractors are constrained by internal and external factors, such as 'waste accepted as inevitable' and lack of interest from clients.

\section{INTRODUCTION}

Around 420 million t of materials are used each year by the construction industry in the UK; however, only 360 million $t$ are incorporated into products. ${ }^{1}$ Additionally, construction and demolition activities in the UK generated more than 150 million t of waste in 1998, comprising 40\% from the manufacture of products and 60\% from site-based activities, including an estimated 13 million $t$ of unused materials. ${ }^{1}$ Previous research on the nature and causes of construction waste established that a variety of materials (such as inert soils, bricks, concrete and packaging) become waste owing to a range of underlying causes, such as design changes, off-cuts and over-ordering. A study by Poon et $a .^{2}{ }^{2}$ concluded that when choosing building materials, designers attached relatively little importance to the potential for waste reduction. It is therefore not surprising that about one-third of construction waste could arise from design decisions. ${ }^{3}$
With increasing waste legislation and fiscal measures in the UK, there is an urgent need to assess the attitudes of both architects and contractors towards waste minimisation in design and construction. Research was thus undertaken to explore current waste minimisation practices, responsibilities and associated barriers in the construction industry in the UK. A number of key themes were identified from literature and government information, and subsequently developed into two questionnaires. These were sent to the top 100 architects and contractors in the UK. The findings of the work could have significant implications should the government put further pressure on the industry to move to a more closed-loop production system.

\section{CONSTRUCTION WASTE MINIMISATION PRACTICES IN THE UK}

This section examines drivers for change and reviews previous research into construction waste quantification and source evaluation. The section concludes by identifying several key research themes which were investigated through an industry questionnaire survey. In the current paper, waste minimisation is defined as the reduction of waste at source, that is designing out waste, by understanding its root causes and re-engineering current processes and practices to alleviate its generation. Similarly, waste management is defined as the process involved in dealing with waste once it has arisen, including: site planning, transportation, storage, material handling, on-site operation, segregation, reuse and recycling, and final disposal. Additionally, design waste is defined as the waste arising from construction sites owing directly or indirectly to the design process.

The key drivers for waste reduction in construction, summarised in Table 1, could be broadly categorised into four main groups, which are environmental, industry and economic concerns in addition to government policies and regulations. The cumulative effect of all of these influences and important new waste management legislation, particularly the Landfill Tax (Amendment) Regulations $2005^{9}$ which came into force in April 2005, should act as clear disincentives to waste production. Such developments come at a critical time because recent data on construction site waste production show it to be unsustainable. ${ }^{1}$

Of the 150 million t of waste arising from construction per annum, ${ }^{1}$ at least $10 \%$ of all materials delivered to construction sites in the UK end up as waste owing to damage, loss and over-ordering. ${ }^{9}$ Although there is anecdotal evidence that the over-ordering culture endemic across the construction sector is 
the result of on-site productivity issues, Poon et al. ${ }^{2}$ identified that this is owing to incomplete contract documentation and frequent design variations during mobilisation stage, resulting in unsuitable or excess materials.

In addition, the total construction, demolition and excavation waste in England was estimated at 91 million t in 2003, up from an estimated 69 million $\mathrm{t}$ in $1999 .{ }^{11}$ In terms of weight, concrete, bricks, blocks and aggregate are by far the major waste streams in the building sector in the UK. ${ }^{12}$ Construction and demolition waste can be divided into three categories

(a) potentially valuable materials, including bricks and concrete

(b) materials that are not capable of being directly recycled but may be recycled elsewhere, including timber and glass

(c) materials that are not easily recycled or present particular disposal issues, including plaster and paints. ${ }^{13}$

McGrath ${ }^{14}$ established that the most significant waste streams on three case studies were inert material (comprising soil removed during the construction and site clean up) and packaging. Poon et al., ${ }^{2}$ however, argued that the composition of on-site waste varied by construction technique, for example, there will be less concrete and timber formwork waste if concrete elements are prefabricated.

The variations in waste composition result in a similar variety of approaches to classify its origins. Bossink and Brouwers ${ }^{15}$ classified sources according to the nature and technology of using materials in building products such as concrete, bricks and wood, whereas Gavilan and Bernold ${ }^{16}$ grouped construction waste sources into design, materials procurement, materials handling, operations and residual or leftover scraps. Similar breakdowns have also been presented by Ekanayake and Ofori ${ }^{17}$ and Serpell and Labra. ${ }^{18}$

It has been estimated that 33\% of wasted materials arise because architects fail to design out waste. ${ }^{3}$ This has, however, been acknowledged to be a complex problem to solve because buildings use a range of materials and methods. ${ }^{19}$ It is made more complex when more waste is created directly or indirectly by other project stakeholders, namely clients, sub-contractors and suppliers.

Nonetheless, there is a general consensus that design changes during the construction phase are one of the key origins of construction waste. ${ }^{15,20}$ In addressing causes of design changes, Poon et al. ${ }^{2}$ conducted a survey of 250 building designers in which they found that potential to reduce waste was ranked last among building designers when selecting building materials.

In summary, a number of factors have increased pressure on the construction industry to improve its waste minimisation practices. Indeed, the key drivers for change, summarised in Table 1, which include legal enforcement, environmental concerns and increasing clients' awareness of environmental requirements, are putting pressure on the construction industry to improve its waste minimisation practices. Legislation, particularly the Landfill Tax, should contribute to a transition away from land-filling towards

\begin{tabular}{|c|c|c|c|}
\hline Environmental concerns & Industry concerns & Economic concerns & $\begin{array}{l}\text { Government policies and } \\
\text { regulations }\end{array}$ \\
\hline
\end{tabular}

Buildings consume $40 \%$ of materials of the world's economy and $75 \%$ of the world's timber. ${ }^{4}$

In the UK the construction sector consumes more than 420 million $t$ of material resources, and generates more than 90 million $t$ of waste per year, including 13 million $t$ of building materials delivered to sites, but never used.'

The construction industry is showing a growing interest and more main contracting companies are seeking ISO 1400 I accreditation. ${ }^{5}$ As the need for assurance of environmental performance is passed down the supply chain, it is inevitable that smaller sub-contractors and suppliers will require accreditation to a similar standard, hence the development of ISO |4002, which will provide guidance for smaller firms on the implementation of ISO I400I audit procedures.
Various initiatives, such as 'Constructing Excellence', aim to exert more influence on the industry and raise awareness of sustainable waste management.

Clients are increasingly demanding improved environmental performance.

Businesses are abandoning their narrow theory of value in favour of a broader approach, which not only seeks increased economic value, but considers corporate social responsibilities and stakeholders' engagement and responsibilities.
Financial benefits are related to the direct costs of both waste disposal and raw material purchase.

The true cost of waste is estimated to be around 20 times the disposal of waste. ${ }^{3}$

The construction industry in the UK spends over $£ 200$ million on Landfill Tax each year. $^{3}$

Businesses can take advantage of government funding to implement waste minimisation practices.

Waste typically costs companies $4 \%$ of turnover with potential savings of $1 \%$ through the implementation of a comprehensive waste minimisation programme. ${ }^{6}$
UK Government has been using a combination of regulation, economic instruments and voluntary agreements.

Waste Strategy 2000 set out a target to reduce by 2005 the amount of industrial and commercial waste sent to landfill to $85 \%$ of that landfilled in 1998. ${ }^{7}$ The strategy focuses more on recycling and recovery of waste rather than waste minimisation.

New legislation, especially the Landfill Tax, the Aggregates Levy and the Hazardous Waste Regulations 2005 will bring about major changes within the field of waste reduction, as the new regulations will make the current waste disposal methods too costly for construction firms.

Site Waste Management Plans (SWMPs), published by the Department of Trade and Industry (DTI), ${ }^{8}$ are a voluntary code of practice, the purpose of which was to assist construction contractors to better manage on-site waste. 
waste reduction, reuse and recycling. As yet, however, this does not appear to have significantly reduced the amount of waste production. The Government in the UK may, therefore, introduce further fiscal measures to mitigate the environmental impacts of construction and demolition activities.

\section{METHODOLOGY}

A number of key issues can be gleaned from literature and related government and industry information. While some studies of waste types and composition exist (e.g. Coventry et al. ${ }^{21}$ ), there is a need for greater clarity on the root causes of waste, thus building on previous research such as Ekanayake and Ofori. ${ }^{17} \mathrm{An}$ increasing body of literature, notably that produced by Coventry and Guthrie, ${ }^{22}$ Keys et al. ${ }^{19}$ and Greenwood, ${ }^{23}$ has demonstrated that the designer has a pivotal part to play in construction waste prevention and minimisation. Furthermore, the finding by Poon et $a l^{2}$ that building designers' low ranking of potential to reduce waste when choosing materials, implies that further research is needed on roles and responsibilities. It is also important to establish the effect that certification schemes such as IS014001 have had on the practices of both designers and contractors. Finally, drivers and barriers should be examined in the context of waste minimisation practices during both the early Royal Institute of British Architects (RIBA) Plan of Work stages ${ }^{24}$ relating to design and, latterly, construction.

Having identified these key issues from the literature, a questionnaire survey was used in this research as a method of collecting data to establish a general industry-wide perspective on causes and origins of construction waste, to examine current waste minimisation practices and responsibilities and to identify barriers that hinder a more proactive approach to adopt and sustain waste reduction measures in construction. The sampling frame was confined to the top 100 architectural practices and contracting firms in the UK, selected respectively from the Architectural Journal Plus and Construction Plus. The Architectural Journal Plus ranking of architectural practices is based on the number of qualified architects within the firms; Construction Plus ranks contractors using an algorithm of turnover, profit, growth, staff employed and earnings per employee. The largest architectural and contracting companies were targeted for this survey because each has considerable and adequate resources in place, which should potentially facilitate the planning, enforcement and implementation of sustainable and holistic waste minimisation strategies in their projects, when compared with small and medium-sized enterprises (SMEs). Partners and associates were targeted within the architectural offices, as they oversee a significant number of projects and lead the decision-making process over the wider context of strategic, design and communication matters within their practices. A similar targeting approach was adopted for contracting firms, where sustainability and environmental managers were selected owing to their interdisciplinary involvement with upstream corporate management and downstream project and site management, in addition to their educational and implementation role in regard to sustainable waste management and insights into current and forthcoming regulatory and compliance issues. In addition, most of these organisations have various offices and construction sites across most regions of the UK.

Two research instruments were developed: one for architects and one for contractors. Both questionnaires were divided into six sections: background information; causes of waste; waste management responsibilities; policies and management plans; waste minimisation practices; and barriers and incentives, some of which were purposely duplicated to obtain comparative insights into common and interrelated issues. The two questionnaires include a combination of rating scales, multiple-choice questions and open-ended questions. The rating scales questions called for the informants to assign an appropriate rating using the five-point Likert scale from ' 1 ', lowest level, to ' 5 ', highest level, to reflect their views on the importance of the listed variables. The multiplechoice questions required them to select the issues/practices that best described their answers. At the end of each thematic section, a space was provided as an option for respondents to accommodate additional information. An optional information question was added at the end of the questionnaire to capture informants' views in regard to other salient waste minimisation and management issues that were not covered in the survey.

\section{RESULTS AND ANALYSIS}

Of the 100 architectural practices surveyed, 40 completed questionnaires were received and of the 100 contractors surveyed, 49 completed questionnaires were received. The overall response rate was therefore $44.5 \%$, which is considered high compared with the norm of $20-30 \%$ in regard to questionnaire surveys in the construction industry. ${ }^{25}$ This particularly high response rate may have been attributable in part to the researcher identifying specific individuals within each company to receive the questionnaire and then following up with regular telephone calls and email reminders in an effort to maximise the response. Responses from both questionnaires were analysed using the statistical package for social science (SPSS). The analysis of the five-point Likert scale questions was carried out by the technique of comparing means by 'one sampling T-test', and the open-ended questions were tabulated manually. The informants' responses to the main themes for the research are examined below.

\section{I. Insights into the causes of construction waste}

Respondents were asked to rate a range of waste causes during design and construction against a five-point Likert scale; the results are shown in Table 2 . Results indicate that "last minute changes due to client's requirements' was accorded the highest mean importance rating by architects and contractors, followed by 'design changes'. When asked to list other causes of waste in the design stage, architects cited 'not designing to minimise waste in mind' and 'not designing for standardisation and to unit sizes' as major contributors: contractors identified 'poor design'; 'inadequate design brief'; and 'not working to standard dimensions' as main causes of on-site waste generation.

During site operations, both architects and contractors agreed that: 'off-cuts from cutting materials'; 'unused materials and products'; 'improper storing space and methods'; and 'waste from application processes' were the major operational waste sources. In terms of weighting, architects considered that 'unused materials and products' was the most important, whereas contractors rated 'off-cuts from cutting materials' as their priority. With regard to further possible causes of waste during construction, architects considered 'lack of forward planning by contractor', 'design changes by contractor' and 'specification and details not being followed' as important. Contractors, however, believed that 'poor management', 'over-ordering', 'untrained/unskilled labour' and 'rejected work/unused materials' were more critical on site. 


\begin{tabular}{|c|c|c|c|c|}
\hline & \multicolumn{2}{|c|}{ Architects' responses } & \multicolumn{2}{|c|}{ Contractors' responses } \\
\hline & Mean & Ranking* & Mean & Ranking \\
\hline \multicolumn{5}{|l|}{ Causes of waste during design stages } \\
\hline Unclear specification & $2 \cdot 78$ & 4 & $2 \cdot 86$ & 5 \\
\hline Design changes & $3 \cdot 75$ & 2 & $3 \cdot 51$ & 2 \\
\hline Detailing errors & $3 \cdot 13$ & 3 & $3 \cdot 22$ & 4 \\
\hline Lack of information on drawings & $2 \cdot 65$ & 5 & $3 \cdot 31$ & 3 \\
\hline Last minute changes due to client's requirements & $4 \cdot 00$ & I & 3.57 & I \\
\hline Delays due to drawing revision and distribution & $2 \cdot 63$ & 6 & $3 \cdot 12$ & 6 \\
\hline \multicolumn{5}{|l|}{ Causes of waste during site operations } \\
\hline Delays in forwarding information on sizes of materials to be used & $2 \cdot 88$ & 6 & $2 \cdot 86$ & 6 \\
\hline Improper storing space and methods & $3 \cdot 63$ & 4 & 3.51 & 2 \\
\hline Unused materials and products & $4 \cdot 30$ & I & $3 \cdot 22$ & 4 \\
\hline Waste from application processes & $3 \cdot 80$ & 3 & $3 \cdot 31$ & 3 \\
\hline Offcuts from cutting materials & $4 \cdot 15$ & 2 & 3.57 & I \\
\hline Weather conditions & $3 \cdot 23$ & 5 & $3 \cdot 12$ & 5 \\
\hline
\end{tabular}

\subsection{Waste management and minimisation responsibilities} Responses relating to waste management and minimisation responsibilities have been presented in Table 3, which indicates that architects take a passive role in waste management. Only around $2 \%$ of architects stated that they organised waste management meetings and 85\% did not analyse the waste that could be generated by their designs. Contractors seem to take the leading role in on-site waste management, with over 73\% adopting waste management goal setting and around 82\% issuing guidelines for on-site waste segregation. This extended to the management of hazardous waste, with over $71 \%$ of contactors issuing guidelines for on-site segregation of both hazardous and non-hazardous waste. All the architects' comments confirmed that they do not have direct involvement with hazardous waste management, other than in health and safety plan statements. Furthermore, architects do not note responsibilities in dealing with hazardous waste in specifications.

\subsection{Environmental policies and sources of information} All respondents were asked about their companies' position as regards to ISO 14001 accreditation. Just 17\% of architects held ISO 14001 certificates compared with $47 \%$ of contractors. There was, however, also clear evidence that many architects and contractors were in the process of seeking accreditation (25\% and
$20 \%$ respectively). On a personal level, more than $81 \%$ of architects and 73\% of contractors said they adopted a self-study approach to education on waste management and minimisation, with a similar number using trade magazines and articles to enhance their knowledge. This suggests that the overwhelming majority of the surveyed companies may not consider waste management training as a significant priority as formal accreditation.

\subsection{Waste minimisation design practices}

Architects were asked to rate the waste minimisation practices that they employed during design; their answers are shown in Table 4. It is evident that very few attempts were being made to minimise waste during the design process; for example, more than $92 \%$ of architects said they did not conduct a feasibility study of waste estimation. Around one-third of the firms claimed, however, that they did use standard materials and prefabricated units frequently, to avoid cutting on site. Architects were also asked about the implementation of such strategies during the RIBA Plan of Work stages. The results of this are shown in Table 5. There was a consensus among the architects that waste minimisation was often not taken on board. More than $80 \%$ of architects said they rarely utilised waste reduction strategies during appraisal, strategic briefing or outline proposals stages.

\begin{tabular}{|c|c|c|c|c|c|c|}
\hline \multirow[t]{3}{*}{ Waste management strategies } & \multicolumn{6}{|c|}{ Response rate: $\%$} \\
\hline & \multicolumn{3}{|c|}{ Architects } & \multicolumn{3}{|c|}{ Contractors } \\
\hline & Yes & No & Total & Yes & No & Total \\
\hline Waste management goal setting & $32 \cdot 5$ & $67 \cdot 5$ & 100 & $73 \cdot 5$ & $26 \cdot 5$ & 100 \\
\hline Analysing site waste to be generated & $15 \cdot 0$ & $85 \cdot 0$ & 100 & $55 \cdot 1$ & $44 \cdot 9$ & 100 \\
\hline Issuing (implementing) guidelines for waste segregation & $30 \cdot 0$ & $70 \cdot 0$ & 100 & $81 \cdot 6$ & 18.4 & 100 \\
\hline Designating waste disposal operators & $15 \cdot 4$ & $84 \cdot 6$ & 100 & $75 \cdot 5$ & $24 \cdot 5$ & 100 \\
\hline Organising waste management meetings & $2 \cdot 5$ & $97 \cdot 5$ & 100 & $37 \cdot 2$ & $62 \cdot 8$ & 100 \\
\hline Issuing (implementing) guidelines for hazardous waste management & $32 \cdot 5$ & $67 \cdot 5$ & 100 & $75 \cdot 5$ & $24 \cdot 5$ & 100 \\
\hline Preparing a list of each waste materials to be salvaged, used or recycled & $30 \cdot 0$ & $70 \cdot 0$ & 100 & $36 \cdot 7$ & $63 \cdot 3$ & 100 \\
\hline
\end{tabular}




\begin{tabular}{|c|c|c|c|}
\hline \multirow[t]{2}{*}{ Waste minimisation design strategies } & \multicolumn{3}{|c|}{ Response rate: \% } \\
\hline & 1 & 2 & Total \\
\hline Feasibility study of waste estimation & $92 \cdot 5$ & $7 \cdot 5$ & 100 \\
\hline Designing for deconstruction & $90 \cdot 0$ & $10 \cdot 0$ & 100 \\
\hline Use of standard dimensions and units & $67 \cdot 5$ & $32 \cdot 5$ & 100 \\
\hline Use of prefabricated units & $65 \cdot 0$ & $35 \cdot 0$ & 100 \\
\hline Specifying reclaimed/recycled materials & $72 \cdot 5$ & $27 \cdot 5$ & 100 \\
\hline Use of standard materials to avoid cutting & $60 \cdot 0$ & $40 \cdot 0$ & 100 \\
\hline Avoidance of late variations in design & $55 \cdot 0$ & $45 \cdot 0$ & 100 \\
\hline Guidance for hazardous waste management & $69 \cdot 5$ & $30 \cdot 0$ & 100 \\
\hline $\begin{array}{l}1=\text { Rarely implemented in design projects } \\
2=\text { Frequently implemented in design projects }\end{array}$ & & & \\
\hline
\end{tabular}

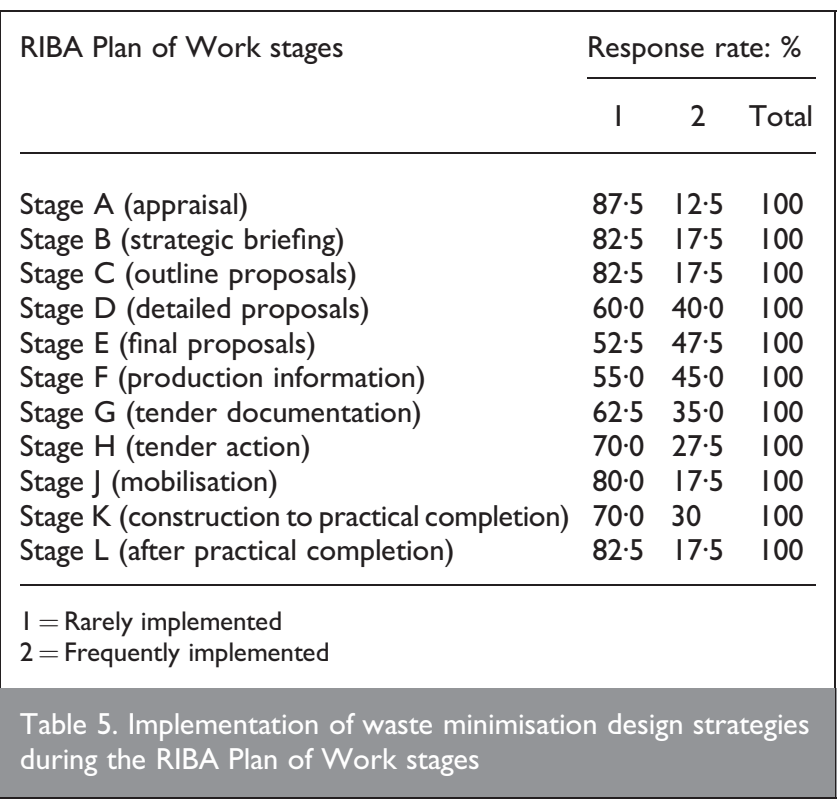

\subsection{On-site waste management practices}

Contractors were asked to rate on-site waste management strategies; their answers are shown in Table 6. It is interesting to note that contrary to expectations the majority of contractors reported that they used 'appropriate storage of materials' (88\%) and 'provided easy access for delivery vehicles' (77\%) in most or

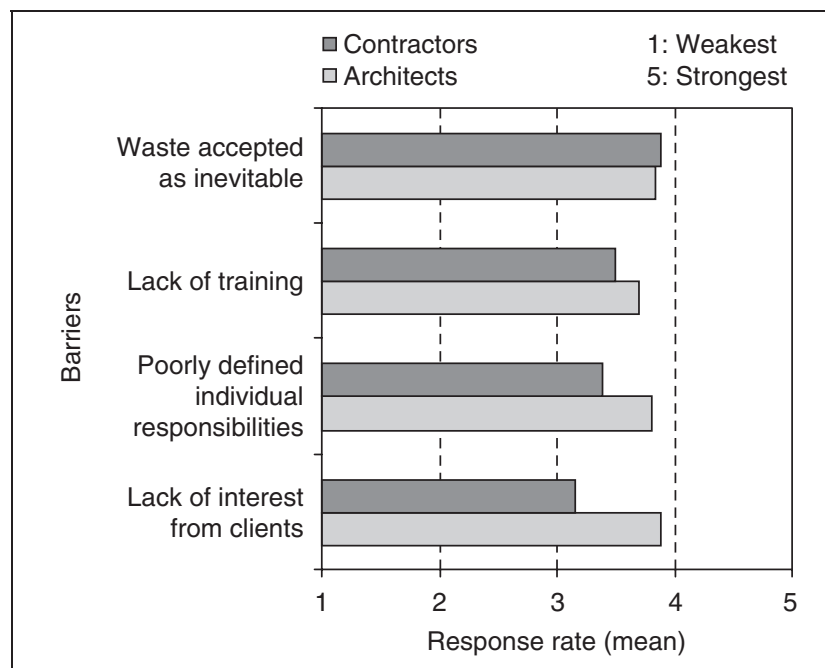

Fig. I. Barriers to construction waste minimisation

all their projects. Few efforts were made, however, to segregate and re-use materials. Indeed, over 26\% implemented on-site segregation of non-hazardous waste and about 12\% and 6\% respectively re-used on-site and off-site waste materials in all their projects. Half of the responding companies, however, said they did set waste reduction targets, which appears somewhat contradictory.

\subsection{Barriers and incentives}

Informants were asked to identify the most influential barriers and incentives relating to waste management, using a Likert scale of 1-5. Their responses are shown in Figs 1 and 2 respectively. Fig. 1 shows that the barrier of "waste accepted as inevitable' was rated the highest mean importance rating by contractors, while architects considered 'lack of interest from clients' as the major constraint, followed closely by 'waste accepted as inevitable' and 'poor defined individual responsibilities'.

There was, however, a greater degree of consistency in respondents' views on major incentives to waste minimisation practices, which is shown in Fig. 2. Both architects and contractors ranked 'financial rewards' and 'legislation' equally as the main incentives that could drive waste minimisation in the construction

\begin{tabular}{|c|c|c|c|c|c|c|}
\hline \multirow[t]{2}{*}{ On-site waste management strategies } & \multicolumn{6}{|c|}{ Response rate: $\%$} \\
\hline & 1 & 2 & 3 & 4 & 5 & Total \\
\hline Set waste reduction targets & $12 \cdot 3$ & $18 \cdot 4$ & $19 \cdot 4$ & $33 \cdot 6$ & $16 \cdot 3$ & 100 \\
\hline Provide easy access for delivery vehicles & $3 \cdot 1$ & $2 \cdot 0$ & $17 \cdot 9$ & $39 \cdot 8$ & $37 \cdot 2$ & 100 \\
\hline Appropriate storage of materials & 0.0 & $6 \cdot 1$ & $6 \cdot 2$ & $46 \cdot 9$ & $40 \cdot 8$ & 100 \\
\hline Non-hazardous waste segregation & $2 \cdot 1$ & $6 \cdot 1$ & $20 \cdot 4$ & $44 \cdot 9$ & $26 \cdot 5$ & 100 \\
\hline On-site reuse of waste materials & $8 \cdot 2$ & $16 \cdot 4$ & $40 \cdot 8$ & $22 \cdot 4$ & $12 \cdot 2$ & 100 \\
\hline Off-site reuse of waste materials & $14 \cdot 3$ & $22 \cdot 4$ & $38 \cdot 8$ & $18 \cdot 4$ & $6 \cdot 1$ & 100 \\
\hline Recycle waste materials & $2 \cdot 0$ & $24 \cdot 6$ & $22 \cdot 4$ & $34 \cdot 7$ & $16 \cdot 3$ & 100 \\
\hline $\begin{array}{l}I=\text { Never been implemented } \\
2=\text { Rarely implemented } \\
3=\text { Implemented in some projects } \\
4=\text { Implemented in most projects } \\
5=\text { Implemented in all projects }\end{array}$ & & & & & & \\
\hline
\end{tabular}




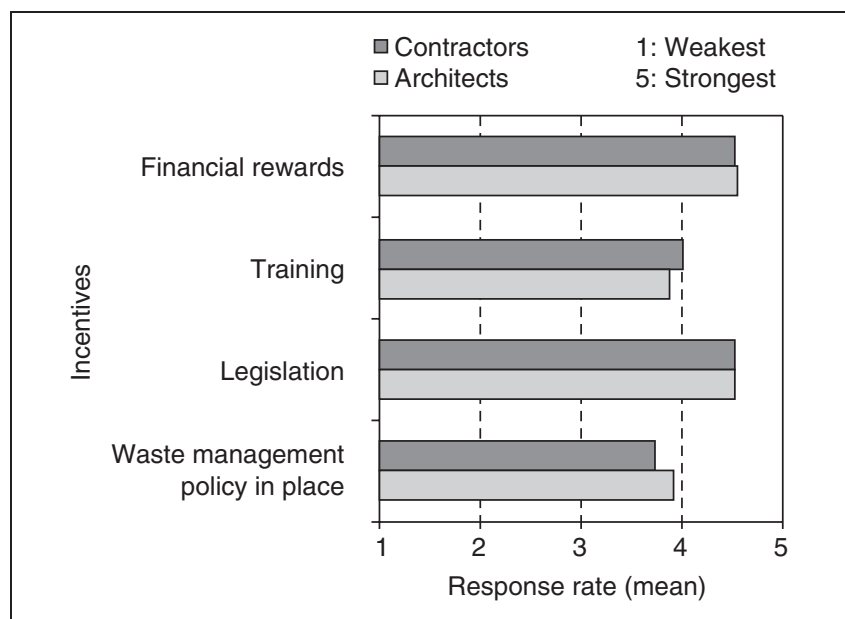

Fig. 2. Incentives to construction waste minimisation

industry. While there is a consensus that legislation can be effective in maintaining the pressure in improving waste minimisation, it was suggested that financial drivers at project level (i.e. allocated fees for architects and reward performance against agreed targets for contractors) and through government initiatives (i.e. tax incentives) will have a far-reaching impact on waste reduction practices. The latter was further emphasised by one respondent who argued that 'the government uses a penal system when a reward system would help clients address the issue with more enthusiasm'.

\section{DISCUSSION}

Although responding architects and contractors concurred that waste is a significant predicament in construction, the industry appears reluctant to implement waste minimisation. The following sections summarise the main themes emanating from the results of both questionnaires, and examine the implications of the survey in the context of the literature.

\section{I. Waste source evaluation}

Respondents related the main origins of construction waste to design, site operations, procurement routes, material handling and sub-contractors' practices. Both architects and contractors considered that 'last minute changes due to client requirements' and 'design changes' were the underlying causes of waste during design. This aligns with findings on design waste by Poon et al., ${ }^{2}$ Bossink and Browers, ${ }^{15}$ Ekanayake and Ofori ${ }^{17}$ and Faniran and Gaban. ${ }^{20}$ This research has identified other significant design waste contributors to be lack of information on drawings, not working to standard dimensions and not designing with waste minimisation in mind. Architects raised concerns regarding design changes by contractors and inaccurate ordering, whereas contractors regarded poor design, inferior design brief and differences between specification and drawings as root causes of on-site waste production. Architects held the contractor responsible for 'lack of forward planning' and 'poor reading of information', including a failure to follow specification and details, whereas contractors argued that waste production was related to buildability, untrained labour, material damage and poor waste management by sub-contractors.

\subsection{Attitudes towards waste minimisation}

Based on the architects' responses, it is clear that waste was not a priority in the design process; they confirmed that waste minimisation strategies are hardly ever implemented. More than 94\% who claimed that no waste was generated during the RIBA Plan of Work Stage A (appraisal), went on to say that they rarely or never used waste minimisation strategies. A similar interpretation can be made for Stage B (strategic briefing). This suggests that architects do not believe that waste is generated during the early stages of design, which is a concerning denial, acknowledged in contractors' views. Architects' perspectives on design waste are in sharp contrast with findings from various studies, revealing that a substantial amount of construction waste is strongly related to design activities., $35,17,20$

On a practical level, over 26\% of contractors consistently implemented some kind of on-site non-hazardous waste segregation, but the ability to segregate waste varied and was seen as highly dependent on site constraints and recycling infrastructure. Although 78\% of contractors acknowledged that the Landfill Tax was having a major impact on current waste management practices, only $16 \%$ had set waste reduction targets and $41 \%$ provided appropriate storage of materials in all their projects.

In dealing with on-site waste, 53\% developed in-house management plans, while $31 \%$ used site waste management plans (SWMPs). ${ }^{8}$ In addition, the overwhelming majority of surveyed design and contracting companies did not consider waste minimisation and management training as a pressing issue. This situation may change when SWMPs, a voluntary code of practice at present, become statutory for all new construction projects in 2007. Although the details of the regulations are not yet finalised, the new powers are likely to have a significant impact on the construction industry's attitudes towards waste, and mechanisms and practices effectively to reduce and manage it. In order to assist design and construction companies in understanding and implementing SWMPs, Envirowise, ${ }^{26}$ in conjunction with WRAP (the Waste and Resources Action Programme), ${ }^{27}$ completed a national series of 15 workshops at the beginning of 2006. Based on the positive feedback from past workshops' attendees, the joint Envirowise-WRAP programme is planning more events in the Autumn 2006. Additionally, other government-funded initiatives are available to provide free advice and guidance on practical ways to increase profits by minimising waste such as Envirowise fast-track visits. ${ }^{26}$ Through an action plan, the latter will highlight areas where savings could be made by means of simple changes that require little or no capital outlay.

Poorly defined responsibilities are leading to confusion on who should control and monitor waste management. Architects argued that waste was an issue for contractors, while contractors countered that a failure to address waste generation in design and poor waste management by sub-contractors were the consequences of a lack of definition regarding roles and responsibilities in a contract. This was echoed by the findings of Poon et $a .^{2}$ (p. 468), who revealed that there had been very few endeavours by architects to adopt waste minimisation strategies, 'which were thought to be the responsibility of the contractor'. In addition, Greenwood ${ }^{23}$ (p. 4) called for a fully integrated waste minimisation system at the contractual stage that "should identify and communicate the responsibilities for waste minimisation between all project stakeholders'.

ISO 14001 certification acts as a process for achieving continuous environmental improvement. The survey results reveal that 
non-ISO 14001 certified architectural firms hardly ever tried to reduce waste. Virtually all the architects without ISO 14001 certification had never conducted a waste estimation feasibility study. The opposite may be true for contractors-over 91\% of contractors with ISO 14001 certification and 88\% of contractors who had a waste management policy argued that they provided proper storage facilities. There was, however, no evidence of a link between waste management policies and contractors' practices in terms of reuse and recycling of waste materials. This aligns with the results of a research study by Poon et $a l^{28}$ who revealed that no correlation was established between ISO 14001 accredited contractors and their waste management practices. Insights into the impact of certified environmental management systems on architects' waste reduction performance is, however, absent from the literature.

\subsection{Constraints and enablers}

About 70\% of surveyed architects and 84\% of contractors believed that training was a major incentive to improving waste minimisation. The results indicate a strong correlation between effective training on waste management and implementation of waste minimisation practices. Indeed, of the responding architects who had not had any training, 68\% rarely or had never implemented waste reduction strategies and 79\% hardly ever or never conducted a feasibility study of waste estimation. Contractors also noted that training to ensure awareness and compliance was a significant challenge, which suggests a general problem with the industry's level of engagement with waste management training.

There was a consensus among both architects and contractors that financial rewards and legislation were key incentives to drive waste minimisation and there was a call also to reward project stakeholders for good waste minimisation performance. Therefore, increased fiscal measures or fines for failing to reduce waste might have a more positive effect on waste minimisation practices than voluntary approaches. Similar results were provided by Lingard et al. ${ }^{29}$ who suggested that a possible encouragement to implementing waste minimisation practices would be the introduction of a reward system for waste reduction and segregation carried out.

Architects reported that client requirements, training and understanding the root causes of waste could act as catalysts for change in design practices. On the other hand, contractors argued that incorporating waste minimisation in the design brief; easy ways to recycle; sub-contractor agreements on waste management practices; and interest from management and awareness of staff could offer improvements. The latter aligns with results from work carried out by Lingard et al., ${ }^{30}$ whose findings suggested that managerial staff consider time, cost and quality to have a much greater significance than environmental issues. It is interesting to note, however, that contrary to the inference of the responding contractors, recent work ${ }^{31}$ has revealed that sub-contractors are of the view that construction waste management is the contractor's responsibility. The same study also identified poor off-loading, storage of materials and poor design as the main causes of on-site waste generation.

Using good practice will help the construction industry to shift towards better waste minimisation practices that will have less impact on the environment and increase cost savings. Indeed, design and construction waste reduction measures were implemented and cost cuts were achieved in the Greenwich Millennium Village (GMV). ${ }^{32}$ Through a partnering effort and the use of the Building Research Establishment (BRE) SMARTWaste, ${ }^{33}$ the GMV project exceeded its 50\% waste reduction target, which resulted in an estimated cost saving of $£ 150000$.

\section{CONCLUSIONS}

Construction waste has been identified by the Government in the UK as a major problem. Within this context, a body of literature is developing which has characterised the types and causes of construction waste. Very few studies have been undertaken, however, on how architects could go about minimising waste through a change in design practices. The present research used a questionnaire survey of the UK's top 100 architects and contractors to investigate the root causes of construction waste, roles and responsibilities, waste reduction strategies in design and construction, and barriers affecting waste minimisation practices.

The results show that most architects were aware of the importance of waste minimisation, but few serious attempts had been made to reduce waste during the design process. Indeed, most architects acknowledged that waste minimisation is not considered during design. In addition, architects believed waste was produced primarily during site operations and rarely generated during the design stages of the RIBA Plan of Work. On the other hand, contractors were pursuing a proactive approach to managing on-site waste through well-defined waste management policies. Contractors strongly believed, however, that waste could be substantially reduced through three focused activities

(a) the design process

(b) better waste management practices by sub-contractors

(c) a change of culture to improve company and individual attitudes.

Both groups appeared, however, to be restrained by internal and external factors, namely, clients' requirements, lack of training, and uncertainty regarding organisational waste minimisation responsibilities and perceptions of waste.

Architects considered waste reduction measures to be the responsibility of contractors, who themselves acknowledged that waste arises from construction and logistical processes. Participants suggested that better-defined organisational and individual responsibilities would help the implementation of measures to reduce waste, perhaps implemented through changes to contractual arrangements or adoption of agreed waste minimisation performance indicators.

It is evident that the construction industry is showing a growing interest in environmental accreditation that could potentially help towards a better waste minimisation performance. There was, however, no clear relationship between companies having ISO 14001 certification and implementing actual waste minimisation activities.

Waste minimisation can be viewed as a threat requiring everincreasing expenditure on end-of-pipe technologies to meet everincreasing legislation or as an opportunity to cut costs and improve performance. Whether or not project teams choose to 
adopt a more proactive attitude towards waste minimisation, the Government may introduce further legislation, which would push the construction industry towards a closed-loop production system. This requires re-engineering current practice to contribute to a cleaner environment through efficient and cost-effective sustainable waste minimisation activities. For waste minimisation to be effective and self-sustaining, however, it is important that all stakeholders along the construction supply chain adopt a more proactive approach in dealing with waste, that is designing out waste. Indeed, the present paper is part of research that aims to create a framework to map the creation of physical waste in design and a method for integrating waste minimisation strategies within building design that would align with a closed-loop approach.

\section{ACKNOWLEDGEMENT}

The authors wish to thank all the companies and individuals who kindly participated in the research. Their time and input is much appreciated.

\section{REFERENCES}

1. Smith R. A., Kersey J. R. and Griffiths P. J. The Construction Industry Mass Balance: Resource, Wastes and Emissions. Viridis, Crowthorne, Berkshire, 2003, VR4, 96.

2. Poon C. S., Yu A. T. W. and JaIlLon L. Reducing building waste at construction sites in Hong Kong. Construction Management and Economics, 2004, 22, June, 461-470.

3. InNES S. Developing tools for designing out waste pre-site and on-site. Proceedings of Minimising Construction Waste Conference: Developing Resource Efficiency and Waste Minimisation in Design and Construction. New Civil Engineer, London, 2004.

4. KNIGHT R. Justifying the short and long term costs of sustainable development. Proceedings of Achieving Sustainable Design Seminar. Royal Institute of British Architects, London, 2003.

5. BALL J. Can ISO 14000 and eco-labelling turn the construction industry green? Building and Environment, 2002, 37, No. 4, April, 421-428.

6. ENVIRowise. Waste Mapping: Your Route to More Profit. Environmental Technology Best Practice Programme, Didcot, Oxfordshire, 1999, ET219.

7. Department of the EnVironment, Transport and the Regions. Waste Strategy 2000. The Stationery Office, London, 2000.

8. Department of Trade and Industry. Site Waste Management Plans Guidance for Construction Contractors and Clients. DTI, London, 2004.

9. The Landfill Tax (Amendment) Regulations 2005: Elizabeth II. Statutory Instrument 2005 No. 759. Her Majesty's Stationery Office, 2005.

10. Guthrie P., Woolveridge A. C. and Coventry S. Managing Materials and Components on Site. Construction Industry Research and Information Association, London, 1998, CIRIA SP146.

11. OfFice of the Deputy PRIMe Minister. Survey of Arisings and Use of Construction, Demolition and Excavation Waste as Aggregate in England in 2003. Her Majesty's Stationery Office, London, 2003.

12. Lawson N., Douglas I., Garvin S., McGrath C., Manning D. and VetTERLein J. Recycling construction and demolition waste-a UK perspective. Environmental Management and Health, 2001, 12, No. 2, 146-157.

13. Guthrie P. and Mallett H. Waste Minimisation and Recycling in Construction: A Review. Construction Industry Research and Information Association, London, 1995, CIRIA SP122.
14. McGrath C. Waste minimisation in practice. Resource, Conservation and Recycling, 2001, 32, No. 3-4, July, 227-238.

15. Bossink B. A. G. and Brouwers H. J. H. Construction waste: quantification and source evaluation. Journal of Construction Engineering and Management, 1996, 122, No. 1, 55-60.

16. Gavilan R. M. and Bernold L. E. Source evaluation of solid waste in building construction. Journal of Construction Engineering and Management, 1994, 120, No. 3, 536-552.

17. EKANAYAKE L. L. and OfoRI G. Construction material waste source evaluation. Proceedings of the 2nd Southern African Conference on Sustainable Development in the Built Environment: Strategies for a Sustainable Built Environment, Pretoria, 2000.

18. Serpell A. and LABRA M. A study on construction waste in Chile. Proceedings of the Joint Symposium of CIB W55, W65 and W107 on Knowledge Construction, Singapore, 2003, pp. 102-111.

19. Keys A., Baldwin A. and Austin S. Designing to encourage waste minimisation in the construction industry. Proceedings of CIBSE National Conference, Dublin, 2000.

20. FAnIRAN 0. 0. and CABAN G. Minimizing waste on construction project sites. Engineering Construction and Architectural Management, 1998, 5, No. 2, June, 182-88.

21. COVentry S., Shorter B. and Kingsley M. Demonstrating Waste Minimisation Benefits in Construction. Construction Industry Research and Information Association, London, 2001, CIRIA C536.

22. Coventry S. and Guthrie P. Waste Minimisation and Recycling in Construction: Design Manual. Construction Industry Research and Information Association, London, 1998, CIRIA SP134.

23. GREenwood R. Construction Waste Minimisation: Good Practice Guide. Cribe, Cardiff, 2003.

24. PhILLIPS R. The Architect's Plan of Work. Royal Institute of British Architects, London, 2006, p. 72.

25. Akintoye A. and Fitzgerald E. A survey of current cost estimating practices in the UK. Construction Management and Economics, 2000, 18, No. 2, March, 161-172.

26. See http://www.envirowise.gov.uk (accessed on 17/07/2006).

27. See http://www.wrap.org.uk (accessed on 17/07/2006).

28. Poon C. S., Yu A. T. W., Wong S. W. and Cheung E. Management of construction waste in public housing projects in Hong Kong. Construction Management and Economics, 2004, 22, No. 7, September, 675-689.

29. Lingard H., Gilbert G. and Graham P. Improving solid waste reduction and recycling performance using goal setting and feedback. Construction Management and Economics, 2001, 19, No. 8, December, 809-817.

30. Lingard H., Gilbert G. and Smithers G. Employee perceptions of solid waste management systems operating in a large Australian contracting organisation: implications for company policy implementation. Construction Management and Economics, 2000, 18, No. 4, June, 383-393.

31. SAnders J. and Wynn P. Attitudes towards waste minimisation amongst labour only sub-contractors. Structural Survey, 2004, 22, No. 3, 148-155.

32. Greenwich Millennium Village: Waste Audit and Minimization Scheme. See http://www.smartwaste.co.uk/ gmv.jsp for further details (accessed on 28/07/2006).

33. SMARTWaste. See http://www.smartwaste.co.uk for further details (accessed on 28/07/2006). 